\title{
Motýl na sněhu
}

\author{
František Všetička \\ (Olomouc, Česká republika)
}

Název uměleckého díla velmi často a poměrně přesně vypovídá o svém tvưrci. To je i př́pad básníŕky Joanny Mossakowské. Její debut z roku 1991 se jmenuje Chvíle (Chwile), a napovídá o své autorce mnohé. Ve stopách starých impresionistů zaznamenává daný stav, chvíli, okamžik, dojem. Pocitová stránka je u ní dominantní. Proto také valná část jejích básní jsou pouze krátké záznamy, jakoby mžitky. Příznačná je v tomto směru už první báseň její první sbírky:

\author{
Wiosna \\ śpiew ptaków kipi mi przez palce \\ Jaro \\ zpěv ptáků kypí mi prsty
}

Strohý záznam, letmý dojem. Pro mistry pera to bylo odraziště, pro Mossakowskou cíl. Miniatury tohoto druhu se táhnou i dalšími svazky. V trètí sbírce nazvané Motýl na sněhu (Motyl na śniegu) je např. takováto drobnost:

mój chtopczyk

$w$ przeciwlegtym lustrze

odwrócony tytem

......

můj chlapec

$v$ protilehlém zrcadle

odvrácený zády 
Je to hranice její tvorby, mez, která se $\mathrm{v}$ jiných textech stává východiskem k obšírnějšímu a prohloubenějšímu poetickému zobrazení.

S miniaturní výpovědí bezprostředně souvisí skutečnost, že Mossakowska př́liš často upouští od názvu básně a nahrazuje jej anonymní hvězdičkou nebo třemi hvězdičkami. V druhé sbírce, nazvané Vytančené větrem (Wytańczone wiatrem), upouští dokonce i od tohoto označení a jednotlivé básně neoznačuje nijak, jsou bez titulu.

Joanna Mossakowska se narodila ve Vratislavi a roku 1982 se přenesla do Zlatých hor, což je pokračování našich Rychlebských hor na polském území. Změna prostředí, v našem př́ípadě podstatná, vnesla do její poezie výrazný př́rodní prvek, projevující se už v titulech její druhé a třetí sbírky - Vytančené větrem a Motýl na sněhu. O básnířčině prírodní inklinaci vypovídá už druhá báseň Motýla na sněhu, v níž zachycuje stárnoucí lípu. Je to ten vysoký strom, rozprostírající své větve před jejím obydlím, jemuž vzdálenou kulisu vytváří stráň Zlatých hor, od níž prodlouženě začíná české, vlastně moravskoslezské území:

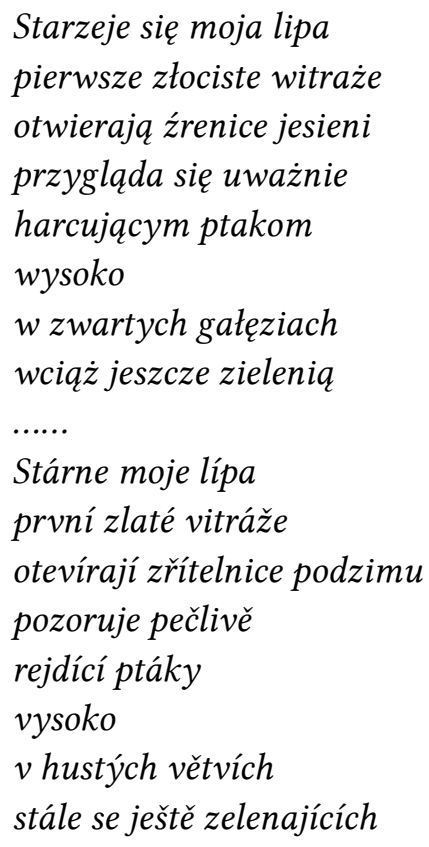

V srdci Zlatých hor leží lázně Lądek-Zdrój, kde Mossakowska žije a pracuje. Střídavě pobývá také v blízkém Orłowci, který je utopen v lesnaté a horské přírodě.

Mossakowska je ovšem nejen básnířka, ale také zručná a pohotová ilustrátorka. Žádnou svoji sbírku sice oficiálně neilustrovala, ale omezenému okruhu svých přátel z rozmaru a z dlouhé chvíle vyzdobí některý ze svých svazků. Vzhledem k tomu, že její 
básně mají miniaturní rozsah, zbývá pro její malî̌ský rozmach na papíre dostatečný prostor. Autorovi těchto řádek tak vyzdobila druhotinu Vytančené větrem. Dokonce barevně.

Básnírka se nejen výtvarně projevuje, ale je zároveň stoupenkyní prolínání jednotlivých umění. Její tvorba se do tohoto úsilí již začlenila prostřednictvím vratislavské výtvarnice Anny Jesinowicz-Nguyen, která do gobelínu vetkala její báseň Cesta do domu (Droga do domu) ze sbírky Motýl na sněhu (tam ovšem - jak je autorčiným pohodlným zvykem - bez titulu). Vietnamské př́zvisko tvůrkyně goblénu pak naznačuje, že jde nejen o prolínání různých umění, ale také o stýkání rozličných národností.

Motýla na sněhu doprovodil fotografiemi básnířčin manžel Leszek Brągiel, nejen fotograf, ale rovněž cestovatel a básník. Jeho fotografie jsou rozmlžené, rozmyté, svým charakterem odpovídají autorčiným básnickým skicám. I ony postrádají výrazné kontury. - Jako básník se Brągiel ubírá zcela jiným směrem, poetika obou je značně rozdílná.

Řekl jsem již na začátku, že Joanna Mossakowska je impresionistický, miniaturistický typ. $V$ tomto směru má básnířka v současném polském kontextu velice blízkou prŕbuznou, jíž je lublinská autorka Eda Ostrowska. Spojuje je strohá, kratičká výpověd, u Ostrowské rovněž někdy dvouveršová. Sbližuje je obdobný pohled na svět - dojmový, pocitový. Jeden z těch nejužších, jaký si lze představit.

\section{About the author}

František Všetička,

Olomouc, Česká republika, fvseticka@seznam.cz 
